\title{
The Iranian policy in the Middle East: evolution and consequences
}

\author{
Mohamed Kamal Mohei \\ Department of Politics, Cairo University, Giza, Egypt
}

\begin{abstract}
Purpose - The purpose of this paper is to study and analyze the Iranian policy towards the Middle East (ME) and its consequences on Egypt.

Design/methodology/approach - This study uses the national interest approach and system analysis approach as analytical framework.

Findings - Several areas are points such as pillars of the Iranian National strategy, pillars of the Iranian policy in the ME and the concept of the Iranian National Security.

Originality/value - Iran is one of the most important and influential regional powers in the Middle East that affects dramatically regional security and stability. The paper analyzes Iranian policy in the $\mathrm{ME}$ and its determinants. In this context, this study deals with the Iranian strategy and Iranian interests. It focuses on the impact of Iranian policy on Egypt and its national security from a comprehensive perspective.
\end{abstract}

Keywords Iranian National Strategy, Iranian Policy, Iranian capabilities, Middle East, Egypt

Paper type Research paper

\section{Introduction}

Over centuries, Iran has been playing an important role in the Middle East (ME). Iran was and still one of the main competitive regional powers. Since the Islamic Revolution in late 1970s, its goals and interests are in conflict with those of the Arab countries, in general, and Egypt, in particular, a matter that increases the importance of the in-depth study of Iranian policy.

The Iranian policy in the ME has taken many aspects in its pursuit to execute its policy in light of the political transformations that occurred in the region. These determinants have served the Iranian project that is based on performing a promising regional role supported by a military force that relies on both conventional and non-conventional capabilities whether related to the nuclear program or the development of the country's rocket forces, in addition to using a number of tools that exist in the region and supported by the political and social environment in the Arab region that witnessed substantial changes following the Arab revolutions in Egypt, Tunisia and Libya, in a way that serves this strategy.

By the end of 2010 and the beginning of 2011, the Arab world was facing a type of transformation that changed the political map. Protests and turbulences that turned into revolutions in Tunisia then Egypt, Bahrain, Libya, Syria and Yemen overthrew a number of regimes and Arab states.

(C) Mohamed Kamal Mohei. Published in Journal of Humanities and Applied Social Sciences. Published by Emerald Publishing Limited. This article is published under the Creative Commons Attribution (CC BY 4.0) licence. Anyone may reproduce, distribute, translate and create derivative works of this article (for both commercial and non-commercial purposes), subject to full attribution to the original publication and authors. The full terms of this licence may be seen at http://creativecommons.org/ licences/by/4.0/legalcode

Received 20 January 2020

Revised 13 March 2020

1 June 2020

9 June 2020

Accepted 12 June 2020 
JHASS

2,4

286

In the regional arena and following the Arab revolutions, various standpoints and different policies regarding the political transformation adopted by a number of countries emerged in the Arab region. The difference in the policies of these countries arises around the way they view the revolutions and the steps or policies that must be followed to avoid the consequences that might lead to negative impacts from one hand or that such positive transformations might be exploited in the regional strategies of active parties in the Arab region on the other hand for Iran had its standpoint and vision concerning the events the Arab world is witnessing and in particular the Egyptian Revolution.

In this context, the main research question of the study is:

$R Q 1$. What are the determinates of the Iranian policy in the ME and its consequences on Egypt?

This includes number of sub-questions as follows:

Q1. What are the Iranian goals and interests in the ME?

Q2. What are the main pillars and tools of the Iranian policy?

Q3. What are the implications of Iranian policy in the ME on Egypt?

Q4. How can Egypt face the Iranian threats to its national security?

Q5. The impact of American policy toward Iran on Iranian policy in the ME?

\section{Pillars of the Iranian national strategy}

The national strategy of the Islamic Republic of Iran is based on the following pillars (Rezaei, 2014):

- The Shiite religious dimension represents one of the most important pillars of the Iranian national security. The Shiite authority is considered the basis for dealing with Iranian security issues. Thus, the Shiite security belt becomes the main guarantor of its external national security. The other cornerstone of the national security is Persian nationalism and its historical implications.

- Iran mixes religion with security to preserve its internal security and overcome its complex ethnic and religious composition.

- The necessity of Persian Iran's domination over the (Persian Gulf) and secure the regional and international recognition. Therefore, it must encounter by all ways and means any efforts or measures that hinder this vision as a fundamental part of the Iranian national security. This requires possessing military, economic and technical capabilities beyond its defense needs that in turn would impose the regional and strategic balance in its favor to become a dominant regional power.

- The theory of the Iranian national security emanates from the dynamics of relations among the various factors influencing the strategic standpoint and the historical vision of Iran's position in the region. These factors are not static, but rather in a state of continuous relative change imposed by the fact that the Persian trend is still continuous and inevitable. Though this trend seems to be limited to a particular region, it is, in the meantime, connected to a larger, ever-changing environment that extends to the whole world.

- The international dimension of the Iranian security is the main actor that influences the national security vision of the Islamic Republic, a matter that persuades Iran 
draft a security theory based on the rights of Iran, with its historical, geographical, human, political, ideological and military reasons, to impose its vital security interests using all possible ways and means to encounter international hostilities regardless of the security interests of others.

- Iran considers that the safety of its borders and interests as well as its religious and cultural values is exposed to great risk. These risks might be external, coming from great countries, in particular, the USA and might be internal coming from the complexity of the ethnic and internal religious structure and the youth generation, a matter that necessitates the availability of all the capabilities required to encounter such risks. Every activity that aims at achieving victory in war and inflicts the maximum losses to the anti-revolution forces, prevents the external invasion of the state and aborts the espionage operations and inflicts sabotage to foreign countries, is considered as an activity that ensures the national security of the Islamic Republic (Mouse, 2012).

- The unity, solidarity and cooperation among the countries of the Gulf region alone are the basis upon which the regional security, from the Iranian point of view, stands. They can be achieved by eliminating the differences among these countries or reducing them to the lowest level especially with regard to border disputes, sectarian differences, ethnic differences and ideological differences (Sariolghalam, 2015).

- Iran considers itself a revolutionary country and a model that can be widely applied in the region. It believes that its revolution embodies its religious value, independence, selfreliance and leadership. It considers its society as ideal where social justice prevails and it possesses the freedom to disseminate its values and principles. However, the sense of threat and injustice that Iran feels and that it is the victim of the reason behind its belief in the principle of "conspiracy"; a matter that augments the difficulty of adaptation with the real world on one hand, and makes it holds on to confrontation, initiative and the establishment of a "Muslim nation" on the other hand.

- Iran believes that the elements of regional security project must be available; the most important of which is the common awareness that Iranian national security is tied to global security, expelling foreign countries from the region and dealing with Israel as an intruding entity that must be wiped out (Sadako, 2012).

- The Iranian national security has several dimensions that make it comprehensive. However, the most important dimension is the economic security, which is the cornerstone in dealing with other elements of security. The economic security according to the contemporary Iranian approach is the result of several factors and that nonconformity of any of these factors leads to the elimination of this security (Alan, 2014).

\section{Pillars of the Iranian policy}

The Iranian policy is based on several pillars that successive Iranian Governments attempt to activate to ensure the impact through Iran's geopolitical position in the region. The strategic location of Iran imposes itself on the reality of the region and the world. Meanwhile, the Iranian capabilities impose itself in the demography field through the dissemination of the Iranian nationalities in the Arab Gulf States in addition to the nature of the Iranian individual himself that is marked with extremism and determination to achieve his pillars of building the political powers determined in the following (Ahmed, 2017): 
$\underset{2,4}{\text { JHASS }}$

288

\subsection{Pillars based on historical factors}

These pillars extend from the Islamic conquest of Persian Empire to the domination of colonialism to the region in the 16th century and the cooperation between the Arab and Iranian rulers in confronting this colonialism. In all times, there was a contact between the Arab and the Iranians, whether in the field of collision or coordination.

\subsection{Pillars based on religious belief}

Iran is the incubator of the Shiite doctrine in Islam and Iran is using the theory of the wilayat al-Faqih to attract the Shiites, through which it achieves its interests. The Shiite sect is characterized by being an inseparable religious/political doctrine. From this point of view, Iran's political orientation towards the Shiite-embracing countries is characterized by privacy in addition to intensifying cooperation with them (Farad, 2011).

\subsection{Pillars based on Iran's own capabilities}

In all fields and, in particular, oil, industry, agriculture and human capabilities.

\subsection{Pillars based on the effectiveness of the diplomatic capacity}

Iranian diplomacy is characterized by the separation between political tensions and common interests. Therefore, Iran's cooperation with most of the world continues in stages when political relations escalate. In the same field, Iran is constantly keen to find a leap in areas of tension or areas of interest to use it when necessary as a stress point to achieve the Iranian goals.

Therefore, the Iranian foreign policy shows the following:

- The doctrine adopted by Iran, which is based on the idea of exporting the revolution, played a vital role in the relationship between Iran and its Arab neighbors. Iran constantly strived to achieve its political goals that are presented in preserving the role of the only state that knew the victory of the Islamic Revolution. In addition, Iran aims at exiting the isolation imposed on it by building a Shiite Muslim State moving towards Shiite minorities outside Iran while taking care of Sunni fundamentalism (Mahmud, 2013).

- The Iranian policy witnessed openness in the era of President Mohammad Khatami, but the arrival of President Ahmadi Nejad to power and the announcement of the need to remove Israel and his clash with the new world regarding the Iranian nuclear program led to strong reactions regarding the Iranian openness to the world. Moreover, the USA attempts to impose a blockade and sanctions on Iran by Security Council resolutions as well as continuing threats of military strikes on Iran's nuclear facilities escalated by both Israel and America (Mark and Joel, 2013).

\section{The concept of the Iranian national security}

The concept of the Iranian national security considers in its dimensions (political, economic, ideological, security, military and informational) the necessity to meet the needs of protecting the revolutionary system, possessing the self-development capabilities and occupying a distinctive position in the international and regional system. This concept is based on five basic hypotheses (Sahara, 2017):

(1) The first hypothesis is derived from the realistic school in international relations. It supposes that the international system is chaotic in which a single superpower tries to impose its domination and control by force without right. 
(2) The second hypothesis is that Iran is forced to live in a permanently hostile environment. Therefore, it can rely only on its own military force to confront this environment and it has only a limited margin for external maneuvering with some of the major powers to protect its security interests.

Iranian policy in the Middle East

(3) The third assumption is that Iran has sufficient strategic depth and borders that can be defended because of the existence of some natural obstacles.

(4) The fourth hypothesis states that Iran enjoys distinctive civilization, ethnicity superiority, human strategic balance in its favor in addition to a distinctive strategic location.

(5) The fifth hypothesis states that Iran believes that it is responsible for establishing the global Islamic system and the inevitability of exporting the Islamic revolution after Islam lost its revolutionary magnificence.

\section{The Iranian interests}

The Iranian interests, according to the national security approach and its applications, are emphasized in the following (Abu, 2014):

- Protecting and securing the Iranian regime in accordance with the values and principles of the Islamic Revolution and working on disseminating them abroad under the slogan of Nusrat Mostazafin and confronting the forces of arrogance.

- Enhancing the regional position of the state, participating in the management of world affairs, investing the international relations in providing technological, economic and human development needs.

- Achieving economic prosperity and welfare for the people and ensuring sustainable development for the benefit of future generations.

- Strengthening the cohesion of society while maintaining the power of Persian nationalism and Shiite sectarian identity.

- Possessing the capabilities for the protection and defense of the state and securing its interests at various levels.

The Arab revolutions created new opportunities for Iran, especially after the fall of Western allies in the Arab region, which means that all efforts of the USA to impose regional isolation had failed. The most important opportunities that Iran gained after the fall of the regimes were in Egypt, Tunisia and Yemen. It is to present the Iranian political model, by creating a new ME based on rubble. The regimes that have fallen, an Islamic ME facing the "Greater Middle East" project. What the United States put forward after the occupation of Iraq (2003), and also the fall of regimesIt contributes to rebuilding relations with these countries.

Iran is now seeking to impose itself as a dominant imperial state at the expense of Arab interests in more than one Arab country, based on its regional expansion project, for which reason, Iran turned to become a strong regional challenge and a source of threat and division for the security and Arab higher interests starting from the Gulf Cooperation Council and extending to many files the most remarkable of which is the nuclear file, the Iranian regional influence file, the intervention in the Arab crises, its direct threat to the Saudi national security and to navigation in Bab al-Mandeb. Such practices unveiled the reality of the Iranian project and its imperial ambitions as declared by the statements of Ali Younis Advisor of the Iranian President Hassan Rowhani, who spoke in a lecture entitled "Iranian 
JHASS 2,4

290

Identity" about the revival of the Iranian Empire and that Iraq was and will remain the capital of that empire. Later on, another Iranian leader states that Iran has become a decision-maker in four Arab capitals: Baghdad, Damascus, Beirut and Sana'a. The comments of the Mehr News Agency, an Iranian semi-official agency, through its Editor, Hassan Hani Zadeh, came to resolve the Iranian perception of Iraq as an "Iranian protectorate" or an "Iranian state" within the Iranian Empire on the land of the Arabs. He called Iraq to unite with Iran on sectarian grounds and persuaded the Iraqis to abandon the false Arabism and the Arab humiliation.

These ideas revealed or rather succeeded in unveiling the reality of the Iranian role, not only in Iraq but also in every Arab country in which the Shiite is of its component. It is clear that the Arab Shiite component, from the perspective of Iranian strategic thinking, is the most significant pillar for the extension and expansion of the Iranian influence. Seizing control over decision-making in the four Arab capitals that were considered subject to the Iranian influence came within the priority of the sectarian dimension or sectarian weapons and resistance and fighting arrogance has nothing to do with this project (Samira, 2013).

The $5+1$ Group of Major Powers (permanent members of the Security Council) also announced The United Nations, as well as Germany, in Switzerland in April 2015, reached an agreement.

Final with Iran on its nuclear program, and the agreement in its general principle provides for the lifting of sanctions international about Iran in exchange for abandoning the military aspects of its nuclear program, while any international parties welcomed the agreement, and other parties, in what Israeli Prime Minister Benjamin Netanyahu described as a "historic mistake", will not enter into force, especially the rift which provides for the lifting of UN sanctions on Iran, until the International Energy Agency ratifies Atomic on Iran's compliance with all its obligations in the agreement, especially with regard to the implementation of Strict control of its nuclear activities and facilities, including some military installations but Despite the signing of the nuclear agreement, the Us House of Representatives approved on November 15, 2016 Bill to extend sanctions on Iran for a period (10) years in order to stop large foreign investments in Iran's energy sector depriving the Iranian regime of the ability to provide financial support to international terrorismAnd the deployment of nuclear weapons.

\section{The impact of the Iranian policy on Egypt}

The Egyptian-Iranian relationships are classified as a model of the oldest bilateral relations between two countries in the modern time. Iran was the only country that had a representation presence in Cairo, prior to February 28, 1922 declaration, which granted Egypt a limited independence under which it obtained certain powers, most notably the right to exchange diplomatic representation. That paved the way to raise the level of diplomatic missions between the two countries as of 1928, with which the frequency of the Egyptian-Iranian interactions increased (Ads, 2014).

Given the regional influence and geo-strategic position of the two countries and the consequent Egyptian and Iranian interests and objectives that are beyond the implementation policies of the geographical borders of the two countries, there were many forms that govern the development of relations between them with the correlation of some of these forms with the historical legacy and what the national obligations dictate.

\subsection{Historical rivalry between the two countries}

- Egypt and Iran, along with Turkey, formed the major regional centers of influence throughout the different historical stages, especially during the modern time, as the 
three countries possess self-sustainability that gives them the right to lead the region along with the rivalry that marked the relationship between the three countries.

- By the interim exit of Turkey from the field of regional rivalry following the First World War, the Ottoman Empire was dismantled and the trend, under the leadership of "Ataturk," to be linked to the Western civilization stream and the negligence of its relations with the countries of the region, the regional rivalry in the ME became confined between Egypt and Iran. Such rivalry was reflected in the policies and attitudes of both countries toward the regional and international developments witnessed in the past century, a matter that affected the nature of relations between the two countries, in particular, with the overlap of this factor with some other factors, on one hand, and the inability of the two countries to find formulas for understanding that would limit the conflict between them on the other hand.

- Within the current developments, it is obvious that Iran trends to strengthen the link with Turkey through the formation of a nucleus of a Southwest Asia Organization (exploiting Turkey's desire to be the gateway of Iranian gas to Europe) that would contain in later stages a strategic bloc that includes Syria, Iraq, Lebanon and Jordan.

\subsection{The ideological conflict between the ruling system in the two countries}

This factor formed one of the main issues of disagreement that affected the nature of the Egyptian-Iranian relations, with contradiction of this conflict differing between the periods of the Shah and the Islamic Revolution. While before the Islamic Revolution, such conflict was focused on the political and security aspects through the engagement in anti-Arab nationalist expansion coalitions, which was led by Egypt, it took the ideological and doctrinal dimension, especially with the adoption, by the new Iranian leadership, of the principle of exporting the Islamic revolution and the confusion between the ideological dimension on one hand and the security and military dimension on the other. This raised security doubts by all countries in the region, including Egypt (Walter, 2015).

It can be said that the relations between Egypt and Iran are historical relations since ancient times. While these relations witnessed different forms of cooperation and convergence in the past few times, they also witnessed various manifestations of divergence and rivalry in some cases. As the two countries belong to one civilization, which is Islamic civilization, there was a great degree of interaction between them at the intellectual and cultural levels. However, there were also some kinds of divergence and extreme disunity between the two countries in other periods, according to each one's vision of the best ways to national interest and the prevailing regional and international changes (Mohammed, 2011).

By tracking the development of the Egyptian-Iranian relations before and after the eruption of the 25th January revolution, we find that it has been influenced by regional files and interventions in the internal affairs of the Gulf States, where a set of internal and external determinants drew the Egyptian-Iranian relations over the various historical stages.

The relations between Egypt and Iran over the past decades prior to January 25th Revolution have been very complex and intertwined, especially in the light of the regional and international developments and changes, a matter that is reflected in the form of the curve of relations between convergence and divergence. 
JHASS 2,4
The relations between Egypt and Iran were affected, before January 25th Revolution by a series of controversial (temporary/continuous) issues represented in Baghdad Pact 1955, The Islamic Alliance, The Egyptian Intervention in Yemen 1962-1967, The Iran-Iraq war 1980-1988, The Arab minority in Iran, Arab-Israeli conflict, the issue of the security of the Arabian Gulf, the New International Order after 1991 and the support of Islamic movements.

Although the January 25th Revolution led to a change in Egypt's relations with the regional and international countries and took clear positions on regional issues, Iran was among the countries that witnessed a breakthrough in relations with Egypt after the January 25th Revolution, as Egypt welcomed relations with Iran and Iran's support of the Egyptian revolution. This breakthrough was remarkably witnessed during the year when former President Mohamed Morsi assumed the presidency of the Arab Republic of Egypt from June 2012 until June 2013. However, tension again dominated the form of the Egyptian-Iranian relations after the outbreak of the June 30th Revolution with the removal of Mohamed Morsi from power and ending the control of the Muslim Brotherhood. In return, the relations between Egypt and Gulf countries improved significantly, contrary to the rule of the Brotherhood, where the relationship between Egypt and the Gulf countries set back (Sahara, 2017).

Iran's pursuit not to escalate its conflicts with the new regime after June 30th quickly changed its position in a way that indicates Iran's desire to establish relations with Egypt regardless of the form of the political system (interest). Despite Iran's attack against the revolution at first because of overthrowing of the Muslim Brotherhood regime and the dismissal of Mohammed Morsi, it quickly reversed its position. This reflects the volatile position of Iran, which shows its awareness of the national interest and pragmatism in its relationship with Egypt and its desire to converge without considering the ruling regime even if Muslim Brotherhood regime is the closest to Iran at many levels.

In relation to the previous presentation, it can be said that the trends of the Iranian policy toward the issues of the region form a number of ramifications on the Egyptian national security, the most notably:

- The possibility of military confrontations in the region, in connection with the expansion of Iranian military in the region, especially in light of the conflicting objectives and interests between most of the Arab countries, on one hand, and Iran, on the other hand, a matter that impacts the national security of Egypt, especially in view of possible involvement in a military confrontation with any non-Arab parties from the perception of defending the Arab national security.

- The growing Iranian military influence increases its ability to enhance its dominance within the countries of the region by inciting terrorist organizations and elements in the region to carry out subversive operations against Arab and Egyptian interests.

- The success of Iran in reaching an agreement with the international parties on the crisis of its nuclear file without Arab/Egyptian participation contributed to enhancing its military influence in the region against the effectiveness of the Arab role, in general, and the Egyptian one, in particular, against the hostile trends of Iran and overlooking the Egyptian vision of not threatening or interfering in the internal affairs of the countries of the region.

- Iran is keen to promote its control over the Strait of Hormuz because of its geostrategic location and escalating its threats to close it, a matter that impacts the Arab and international interests as well as the passage of most oil tankers through the Suez Canal, resulting in reducing the revenues expected to be realized. 
- The increasing influence of Iran in the region has many repercussions on the Egyptian national security, as it reduces the effectiveness/influence of the Arab role, in general, and the role of Egypt, in particular, in resolving crises in the region, especially in light of the international forces' tendency to rely on non-Arab parties in resolving the issues of the region.

- Iran's pursuit to lead the regional system in the Gulf region with its security, political and economic arrangements through dissemination and expansion in the region politically/militarily without Egyptian participation, which limits the effectiveness/impact of the Egyptian role and increases the complexity of the security situation in the region (Mohammed, 2018).

- Iran uses the Palestinian issue with all its dimensions to rally support for its policies in the Arab and Islamic streets regardless of Palestinian and Arab interests.

- Linked to the increasing instability in the region, driven by Iran through stoking hotbeds of tension/conflict, both directly/indirectly, which adversely impacted the size of the investments received by Egypt and consequently the Egyptian economy in general.

- Widening the scope and ramifications of military operations in the majority of the Gulf countries adversely impacted the Egyptian economy through the return of part of the Egyptian expatriates from Gulf countries as well as the decline in tourism revenues and the size of intra-regional trade with the countries of the region.

Amidst of all these complex developments and in view of the assertion of the present President Abdel Fattah El Sisi that the relation between Egypt and Iran is governed by Iran's noninterference in the security and stability of the Gulf, especially with the improvement of Egyptian-Gulf relations after the June 30th revolution, the Egyptian decision-maker has to consider the following facts:

- Develop mutual cooperation with the countries of the region and mobilize international support to contain the Iranian role toward issues of the region, which impedes a political settlement of these issues and increases its complexity and adversely affects the security and stability of the region.

- Placing pressure on the State of Qatar to push it return to the Arab front and abandon its support of terrorism to abort Iran's attempts to exploit the situation and the tension among the parties of the Gulf crisis to execute its plan/intentions in the region (Mohamed, 2018).

- The need to formulate a political vision to resolve the issues of the region, giving priority to the issues of "Syria - Iraq - Yemen" to deprive Iran from using such issues as tools to achieve its interests with the importance of consultation and expanding the dialogue for future security arrangements with all concerned parties in the region.

- Considering not to be dragged behind stirring ethnic and sectarian gaps in the region, as they serve only the interests of the forces and parties that seek to promote this thought and feed scenarios of sectarian conflict (Shiite - Sunni).

All these developments call the people of the region to consider the development of the Gulf alliances by concluding a strategic merger and partnership with Egypt to establish a new structure for Arab security that might be the first step toward the reconsideration of new security perspective that do not give priority to military security. Here, we can talk about 
JHASS 2,4

new alliances with regional parties that Iran might be part of provided that Iran reviews its policies and trends.

In the end, regional dialogue must be moved, as Iran wants in opening a dialogue with the countries of the region, in general, and the Egyptian state, in particular, on issues of specific regional disputes between them and these countries within the framework of the "Regional Dialogue Complex." The most important issues discussed are terrorism, extremism, the conflict in Yemen and the conflict in Syria. This trend is based on a traditional strategy based on the idea of building trust in collective issues.

Through dialogue and avoiding raising contentious issues of a bilateral nature in the early stages Where it is put forward in the next stages after the start of the dialogue more effective and which is considered according to A funny expression that "doctrinal arguments and personal differences", and it must be borne in mind that experiences Similar international reveals that the success of dialogue between asymmetric parties in power or status It requires a reliable guarantor from all sides and is able to provide incentives and hence the Egyptian role that is able to achieve Balance in the Arab region.

There is no doubt that the complexities of the Iranian crisis and its multiple dimensions (security, political, economic and ideological) and the threats and challenges posed by its development scenarios toward regional security drive the importance of the continuous review of the strategy of dealing with Iran in accordance with a comprehensive and integrated strategic thinking. And use all resources and tools to achieve national and national interests and objectives.

\section{References}

Abu, V. (2014), Iranian Trends in the Arab Region and Their Impact on National Security, Second Edition, Sadiq Center Library, pp. 89-91.

Ads, T. (2014), "Prospects for the development of Egyptian-Iranian relations", Magazine Iranian Anthology, Cairo: Center for Political and Strategic Studies in Al Ahram, No. 130, p. 65 May.

Ahmed, A. (2017), "The influence of the political leadership on Iran's foreign policy: a comparative study between Mahmoud Ahmadinejad and Hussein Rohani”, Master Thesis, Cairo University, Faculty of Economics and Political Science, pp. 58-63.

Alan, C. (2014), Security and Southeast Asia: Domestic, Regional and Global Issues, Lynne Rienner Publishers, London, pp. 9-10.

Farad, K. (2011), "The Islamic revolution in Iran: retrospect after a quarter of a century", Thesis Eleven, Vol. 70 No. 76, p. 75.

Mahmud, S. (2013), "The foreign policy of the Islamic Republic of Iran: theoretical renewal and a search for paradigm", Iranian Quarterly, Vol. 4 No. 4, pp. 21-26. .

Mark, K. and Joel, K. (2013), Introduction to Comparative Politics: Political Challenges and Changing Agendas, 5th edition, Engage Learning, Boston, Wadsworth, p. 608.

Mohamed, I. (2018), The Determinants of Egyptian - Gulf Cooperation in the Light of the Developments of the US-Iranian Crisis, Al Ahram Foundation, The International Politics, No. 214, October, pp. 122-130.

Mohammed, N. (2011), "The future of the regional role of Iran after the Arab revolutions", AlAhram Foundation, the International Politics, April, No. 184, p. 52.

Mohammed, K. (2018), "Why is Iran a regional dilemma?", AlAhram Foundation, the International Politics, No. 214, pp. 76-79.

Mouse, Q. (2012), “The regional role of Iran in the Middle east during the period from 1991 to 2010", Master Thesis, Cairo University, Faculty of Economics and Political Science, pp. 67-68. 
Rezaei, A. (2014), Foreign Policy Theories: Implications for the Foreign Policy Analysis of Iran, in Iran s Foreign Policy from Khatami to Ahmad Inejad, in Ehteshami, A. and Zawierci, M. (Eds), Ithaca press, London, pp. 17-21.

Sadako, O. (2012), "The final report of the commission on human security", State Security and Human Security: Human Security Now, Commission On Human Security, New York, NY United Nations, p. 5 .

Sahara, H. (2017), "The impact of the Turkish-Iranian competition on regional security in the Middle east (2002-2015)", PhD, Cairo University, Faculty of Economics and Political Science, pp. 110-113.

Samira, A. (2013), "The impact of economic sanction on Iran's economy and foreign policy", Washington Dc, pp. 1-5.

Sariolghalam, M. (2015), "Globalization and Iran national sovereignty: challenge of compatibility", Iranian Quarterly, Vol. 5 No. 3, pp. 21-26.

Walter, P. (2015), The Third World, Global Islam and Pragmatism: The Making of Iranian Foreign Policy, Berlin, German Institute For International and Security Affairs, pp. 9-10.

\section{Corresponding author}

Mohamed Kamal Mohei can be contacted at:m.moheiA7@yahoo.com

For instructions on how to order reprints of this article, please visit our website: 